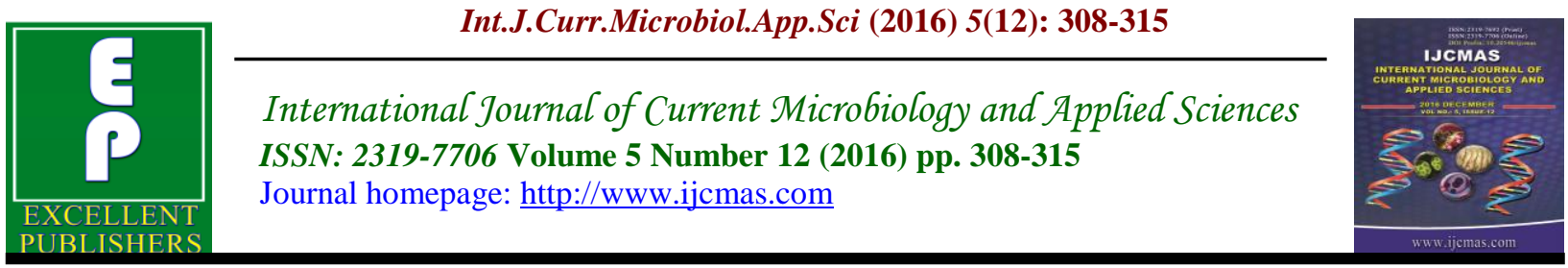

Original Research Article

http://dx.doi.org/10.20546/ijcmas.2016.512.033

\title{
Seasonal Variation in Physico-Chemical Parameters of Water in Laxmi Taal, Jhansi, India
}

\author{
Tirthesh Kumar Sharma* and Ramendra Singh
}

\author{
Department of Botany and Industrial Microbiology, Bipin Bihari P.G. College, \\ Bundelkhand University, Jhansi, India 284001 \\ *Corresponding author
}

\begin{abstract}
A B S T R A C T
Keywords

Seasonal, Wastewater treatment, Water Resources, Sewage, waste water.

Article Info

Accepted:

12 November 2016 Available Online:

10 December 2016

People on globe are under tremendous threat due to undesired changes in the physical, chemical and biological characteristics of air, water and soil. Due to increased human population, industrialization, excess use of fertilizers and other man made activities water is highly polluted with different harmful contaminants. During the investigation of heavy metals and physicochemical parameters of water in Laxmi Taal, Jhansi City was analyzed to determine the water quality seasonally in the year of August 2014 to May 2015. Some physicochemical parameters such as temperature, $\mathrm{pH}$, Conductivity, Salinity, Turbidity, TDS, TS, TSS, Alkalinity, Hardness, $\mathrm{Ca}++, \mathrm{Mg}++$, Free $\mathrm{CO}_{2}$, Chloride, DO, BOD, chemical oxygen demand, total organic carbon and heavy metal such as Zinc, Lead and Iron were evaluated. Environmental temperature varied between $25^{\circ} \mathrm{C}$ to $44^{\circ} \mathrm{C}$, water temperature 21.5 to 36.2 , PH 7.8 to 8.7 , Conductivity 1015 to $1120(\mu \mathrm{H})$, Salinity 503 to 530 , turbidity 112 to $125 \mathrm{NTU}$, total dissolved solid 713 to $760 \mathrm{mg} / \mathrm{L}$, total suspended solid 513 to $564 \mathrm{mg} / \mathrm{L}$, alkalinity 162 to $175 \mathrm{mg} / \mathrm{L}$, hardness 265 to $387 \mathrm{mg} / \mathrm{L}, \mathrm{Ca}^{++}$ 55 to $77 \mathrm{mg} / \mathrm{L}, \mathrm{Mg}^{++} 201.5$ to $261 \mathrm{mg} / \mathrm{L}$, free $\mathrm{CO}_{2} 484$ to $243.5 \mathrm{mg} / \mathrm{L}$, Chloride 116 to $144 \mathrm{mg} / \mathrm{L}$, DO 0.90 to $2.4 \mathrm{mg} / \mathrm{L}$, BOD 4.10 to $8.20 \mathrm{mg} / \mathrm{L}$, COD 212.3 to $215.3 \mathrm{mg} / \mathrm{L}$ and TOC 88.79 to $90.2 \mathrm{mg} / \mathrm{L}$ and heavy metals such as Zinc varied between 1.20 to $1.27 \mathrm{mg} / \mathrm{L}$, lead 0.80 to $0.83 \mathrm{mg} / \mathrm{L}$ and iron 2.60 to $2.70 \mathrm{mg} / \mathrm{L}$. This study reveals that water of Laxmi Taal is partially polluted with heavy metals and imbalanced of physicochemical parameters. It is recommended that strict vigilance and constant monitoring are needed to maintain water quality of this Taal, which is a major source of potable water for Jhansi City.
\end{abstract}

\section{Introduction}

Approximately $71 \%$ of the earth's surface is covered with water. It is an essential requirement of human and industrial developments and it is one of the most delicate parts of the environment (Okake and Igboanua, 2003). Water quality is a term that is most frequently used, but rarely defined, probably because it has no fixed definition, but apparently fairly well understood by users. Thus, the quality of water is a reflection of the source environment and the activities of man, including the use and management measures. However, the desirable properties 
of water quality should include: Adequate amount of dissolved oxygen at all time, a relatively low organic content, $\mathrm{pH}$ value near neutrality, moderate temperature, and freedom from excessive amount of infectious agents, toxic substances and mineral matter (Adeniyi, 2004). Water quality refers to the physical, chemical and biological characteristics of a water body. These characteristics determine how and for what water can be used and the species and ecosystem process it can support. Good quality of water resources depends on the large number of physicochemical parameters and the magnitude and source of any pollution load and to assess that monitoring of these parameters is essential (Reddi et al., 1993).

The addition of various kinds of pollutants and nutrients through the agency sewage, industrial effluents, agricultural runoff etc. into the water bodies brings about a series of changes in the physicochemical and characteristics of water, which have been the subject of several investigations (Mahananda et al., 2010). Various factors are responsible for water pollution, which makes it quite undesirable for portability. Such factors include: Sewage discharge, which contributes to oxygen demand and nutrient loading to a destabilized aquatic ecosystem (DWAF WRC, 1995). The water quality is directly related to the health of the water body and directly linked to human welfare. So, proper management in water quality of aquatic environment is very much essential. Some of the most recent works on water quality of various aquatic environments was those of Gopalkrushna (2011), Offem et al., (2011), Vaishnav and Dewangan (2011), Iwuoha and Osuji (2012), Matini et al., (2012), Devi et al., (2013) and Tamrakar and Raj (2013).

Seasonal variations in quality of water generally refer to the change in components of water, which are to be present at the optimum level for suitable growth of plants and animals. These components play an important role for the growth of plants and animals in the water body. The regular and periodic changes in the climate synchronized with season are ultimately reflected in the environmental parameters also, which in turn have a direct or indirect influence over the planktonic population as well as living beings. The seasonal distribution, abiotic and biotic processes affect the nutrient cycle of different coastal environments (Choudhury and Panigrahy, 1991).

The purpose of the present study is to observe water quality of Laxmi Taal situated in middle of jhansi city Uttar Pradesh by physico chemical procedures and to determine the changes in water quality parameters by seasons and to find the relationship between different physico chemical parameters. It is undertaken to access the effect of seasonal variation on water quality in rainy, winter and summer seasons. The objectives of the present work were to (1) To assess physico-chemical characteristics of water of Laxmi Taal in four different seasons (2) To establish the correlation between the parameters and the seasons. This study was conducted during August 2014 to May 2015, at different sampling sites of laxmi Taal, Jhansi. This work is therefore aimed at studying the water quality as well as it's seasonal variation.

\section{Materials and Methods}

\section{Study site}

The study was conducted for a period of one year from August 2014 to May 2015 at Laxmi Taal, in Jhansi city, Uttar Pradesh, India. Laxmi Taal is the lake located in old Jhansi, that is built during the early $18^{\text {th }}$ 
century, and was main source of water to the city that flourished within the fort walls. In present day the Taal is popular place to visit, albeit very ill- maintained too. At present Laxmi Taal is suffer from pollution due to antropogenic sources. Weed are well developed and causes eutrophication in Lake. It co ordinates Between $25^{\circ} 27^{\prime} 36^{\prime \prime} \mathrm{N}$ to $78^{\circ} 35^{\prime} 33^{\prime \prime} \mathrm{E}$.

\section{Sample collection}

Seasonal collections were made to record the physico-chemical characteristics of water. The samples thus collected were grouped to represent different seasons of a calendar year viz., quarterly mid monsoon (Aug) after monsoon (Nov) before summer (March) and summer (May). The water samples were collected from Laxmi Taal at quarterly intervals from August 2014 to May 2015 during $10.0 \mathrm{am}-1.00 \mathrm{pm}$ in sterilized plastic bottles. The closed bottle was dipped into the water and then the cap is opened and water is allowed to fill up the bottle absolutely. The cap is then closed and the bottle is bring out of the water and carried to laboratory for analysis of water quality. Several physico chemical parameters such as water temperature, $\mathrm{pH}$, Salinity, turbidity, dissolved oxygen $\left(\mathrm{DO}_{2}\right)$, free carbon dioxide $\left(\mathrm{FCO}_{2}\right)$, alkalinity, electrical conductivity, total solid(TS). Total suspended solids (TSS), total dissolved solids(TDS), Hardness, $\mathrm{Ca}++, \mathrm{Mg}++, \quad$ chloride $(\mathrm{Cl})$, biochemical oxygen demand (BOD), chemical oxygen demand (COD), total organic carbon (TOC) and heavy metal such as Zinc, Lead and Iron were evaluated.

Temperature of the water samples was recorded at the time of collection by using digital thermometer. $\mathrm{pH}$ of water samples were determined by using portable $\mathrm{pH}$ meter. The $\mathrm{pH}$ meter was carefully calibrated with standard $\mathrm{pH}$ 7. Properties such as chloride, free $\mathrm{CO}_{2}$, dissolved oxygen, electrical conductivity, salinity, total dissolved solids, total solid and suspended solid, and turbidity alkalinity of water were determined following standard methods given by Welch (1952), Trivedy and Goel (1984), Wetzel and Likens (1991) and APHA (2005). Total hardness was estimated by the complexometric titration with standard EDTA solution using Eriochrome Black-T as indicator. Chemical oxygen demand was determined by Himebaugh and Smith (1979). Total organic corbon was analaysed by Williams(1969). Heavy metals were analyzed by using Mass spectrophotometer (Agilent7300)

\section{Results and Discussion}

\section{Environmental temperature and water temperature}

Water temperature is one of the essential parameter, so it influences the growth of flora and fauna. Quarterly variations in physicochemical parameters viz., Environmental and water temperature, salinity, $\mathrm{pH}$ in water Samples were recorded. During the study period environmental temperature varied from $25^{\circ} \mathrm{C}$ to $44^{\circ} \mathrm{C}$ and water temperature from $21.5^{\circ} \mathrm{C}$ to $36.2^{0} \mathrm{C}$. Both environmental and water temperature were recorded minimum in February and maximum in May.

\section{pH}

The $\mathrm{pH}$ value ranged between 7.8 to $8.7 . \mathrm{pH}$ of Laxmi Taal was slightly alkaline during all seasons but recorded minimum in May and maximum in August. The higher range of $\mathrm{pH}$ indicates the higher productivity of water. $\mathrm{pH}$ expresses the intensity of acidity or alkalinity of an aquatic environment. No significantly variations were observed in duration of this study. 


\section{Electrical conductivity}

The conductivity was ranged from 1015 to $1120 \mu \mathrm{H}$ in water samples that showed their higher ionic conductance during Before summer, summer and before mansoon due to discharge of huge quantities of electrolytes from different sources. But during after monsoon (November), conductivity showed declination in samples. This was due to huge dilution of water by the monsoon rainfall and upstream flow of water.

\section{Salinity}

Salinity varied from 503 to 530 which was maximum in May and minimum in November. It was done due to high loss of water by evaporation during summer high dilution during rainy season.

\section{Turbidity}

Turbidity is another indicator of the amount of material suspended in water. It measures the amount of light that is scattered or absorbed. Suspended silt and clay, organic matter, and plankton can contribute to turbidity. In after monsoon the concentration of chemical parameters show decrease trend due to dilution effect by the surface run-off received during rainfall (Srivastava et al., 2011). The average concentration of Turbidity found was higher in after monsoon i.e. 125 NTU due to surface runoff of rainfall decreased after the settling of suspended matter, which showed the decrease up to 13NTU in summer supported the statement of Srivastava et al., 2011.

\section{Total Solid, Total disolved solid, Total suspended solid}

Total Solid varied from 1120 to $1320 \mathrm{mg} / \mathrm{l}$. It was maximum in summer and minimum in after monsoon. The TDS varied from 713 to $760 \mathrm{mg} / \mathrm{l}$. The maximum TDS was recorded during the month of November (After monsoon) and the minimum was observed during the month of May (summer). Total suspended solid varied from 513 to $564 \mathrm{mg} / \mathrm{l}$. Maximum TSS was recorded in summer (May) and minimum in February.

\section{Alkalinity, total Hardness, $\mathrm{Ca}^{++}$hardness, mg $^{++}$hardness}

Alkalinity is the capacity to neutralize acids, and the alkalinity of natural water is derived principally from the salts of weak acids. Hydroxide, carbonates, and bicarbonates are the dominant source of natural alkalinity. Reactions of carbon dioxide with calcium or magnesium carbonate in the soil creates considerable amounts of bicarbonates in the soil. Organic acids such as humic acid also form salts that increase alkalinity. Alkalinity itself has little public health significance, although highly alkaline waters are unpalatable and can cause gastrointestinal discomfort. Alkalinity varied from 162 to $175 \mathrm{mg} / \mathrm{l}$ and total hardness between 265 to $387 \mathrm{mg} / \mathrm{l}$. Both of these were maximum in summer (May) and minimum in after monsoon. Total hardness is the parameter of water quality used to describe the effect of dissolved minerals (mostly $\mathrm{Ca}$ and $\mathrm{Mg}$ ), determining suitability of water for domestic, industrial and drinking purpose attributed to presence of bicarbonates, chloride and nitrates of calcium and magnesium (Taylor, 1949). Ca++ and $\mathrm{mg}$ hardness varied from 55 to $77 \mathrm{mg} / \mathrm{l}$ and 201 to $261 \mathrm{mg} / \mathrm{l}$.

\section{Free $\mathrm{CO}_{2}$}

Free $\mathrm{CO}_{2}$ varied from 228 to $484 \mathrm{mg} / \mathrm{l}$. It was maximun in before mansoon (August) and minimum in after monsoon (November). It was increased due to increase in 
concentration of microorganism during summer season.

\section{Chloride}

Chloride is a major anion in potable and industrial water has no adverse effect on health, but imparts bad taste to drinking water. The chloride concentration serves as an indicator of pollution by sewage. People accustomed to higher chloride in water are subjected to laxative effects (Fried and Combarnous1971). A high concentration of chlorides affects growth of vegetation and imparts an increase in corrosiveness of metals. Chloride in excess of $100 \mathrm{mg}$ per litre imparts a salty taste and may cause physiological damages. Water with high chloride content usually has an unpleasant taste and may be objectionable for some agricultural purposes.

The chloride concentration varies from sample to sample. Chloride imparts a permanent hardness to the water. Although hardness does not have adverse health effect they make water unsuitable for general domestic purposes and in the presence of calcium and magnesium even $1 \mathrm{~g} / \mathrm{l}$; chloride does not impart bad taste due to formation of $\mathrm{MgCl} 2$ and $\mathrm{CaCl} 2$. In this study chloride ranged between 116 to $144 \mathrm{mg} / \mathrm{l}$ and maximum in May and minimum in November.

Table.1 Phsicochemical parameters of water from Laxmi taal during 2014-15

\begin{tabular}{|l|l|l|l|l|l|}
\hline S.No. & Parameters & Aug. (2014) & Nov.(2014) & Feb. (2015) & $\begin{array}{l}\text { May. } \\
(2015)\end{array}$ \\
\hline 1. & Envir. temTc) & 36.20 & 34.0 & 25.0 & 44.0 \\
\hline 2. & Water tm(T $\left.{ }^{0} \mathrm{C}\right)$ & 34.80 & 28.50 & 21.50 & 36.20 \\
\hline 3. & PH & 7.80 & 8.70 & 8.20 & 8.10 \\
\hline 4. & Conductivity(uH) & 1022.0 & 1015.0 & 1095.0 & 1120.0 \\
\hline 5. & Salinity & 513.0 & 503.0 & 508.0 & 530.0 \\
\hline 6. & Turbidity(NTU) & 120.0 & 125.0 & 115.0 & 112.0 \\
\hline 7. & TDS(mg/L) & 713.0 & 760.0 & 758.0 & 745.0 \\
\hline 8. & TS(mg/L) & 1280.0 & 1120.0 & 1265.0 & 1320.0 \\
\hline 9. & TSS(mg/L) & 519.0 & 520.0 & 513.0 & 564.0 \\
\hline 11. & Alkalinity(mg/L) & 162.0 & 168.0 & 169.0 & 175.0 \\
\hline 12. & Hardness(mg/L) & 265.0 & 355.0 & 355.0 & 387.0 \\
\hline 13. & Ca & 55.0 & 70.50 & 69.50 & 77.0 \\
\hline 14. & Mg ${ }^{++}$ & 201.50 & 243.0 & 247.0 & 261.0 \\
\hline 15. & Free CO $(\mathrm{mg} / \mathrm{L})$ & 484.0 & 228.40 & 230.0 & 243.50 \\
\hline 16. & Chloride(mg/L) & 127.80 & 116.0 & 130.50 & 144.0 \\
\hline 17. & DO(mg/L) & 1.10 & .90 & 2.40 & 1.40 \\
\hline 18. & BOD(mg/L) & 5.20 & 4.10 & 6.0 & 8.20 \\
\hline 19. & COD(mg/L) & 212.30 & 215.30 & 215.30 & 214.0 \\
\hline 20. & TOC(mg/L) & 88.79 & 89.50 & 89.50 & 90.20 \\
\hline
\end{tabular}


Table.2 Determination of trace element of water from Laxmi taal during 2014- 15

\begin{tabular}{|l|l|l|l|l|l|}
\hline S.No. & Parameters & Aug. (2014) & Nov.(2014) & Feb. (2015) & May. (2015) \\
\hline 1. & $\mathrm{Zn}(\mathrm{mg} / \mathrm{L})$ & 1.20 & 1.28 & 1.28 & 1.27 \\
\hline 2. & $\mathrm{~Pb}(\mathrm{mg} / \mathrm{L})$ & 0.80 & 0.83 & .082 & 0.83 \\
\hline 3. & $\mathrm{Fe}(\mathrm{mg} / \mathrm{L})$ & 2.67 & 2.60 & 2.63 & 2.70 \\
\hline
\end{tabular}

Fig.1 Laxmi taal containing different sampling site of water collection for physicochemical analysis during seasonal variation

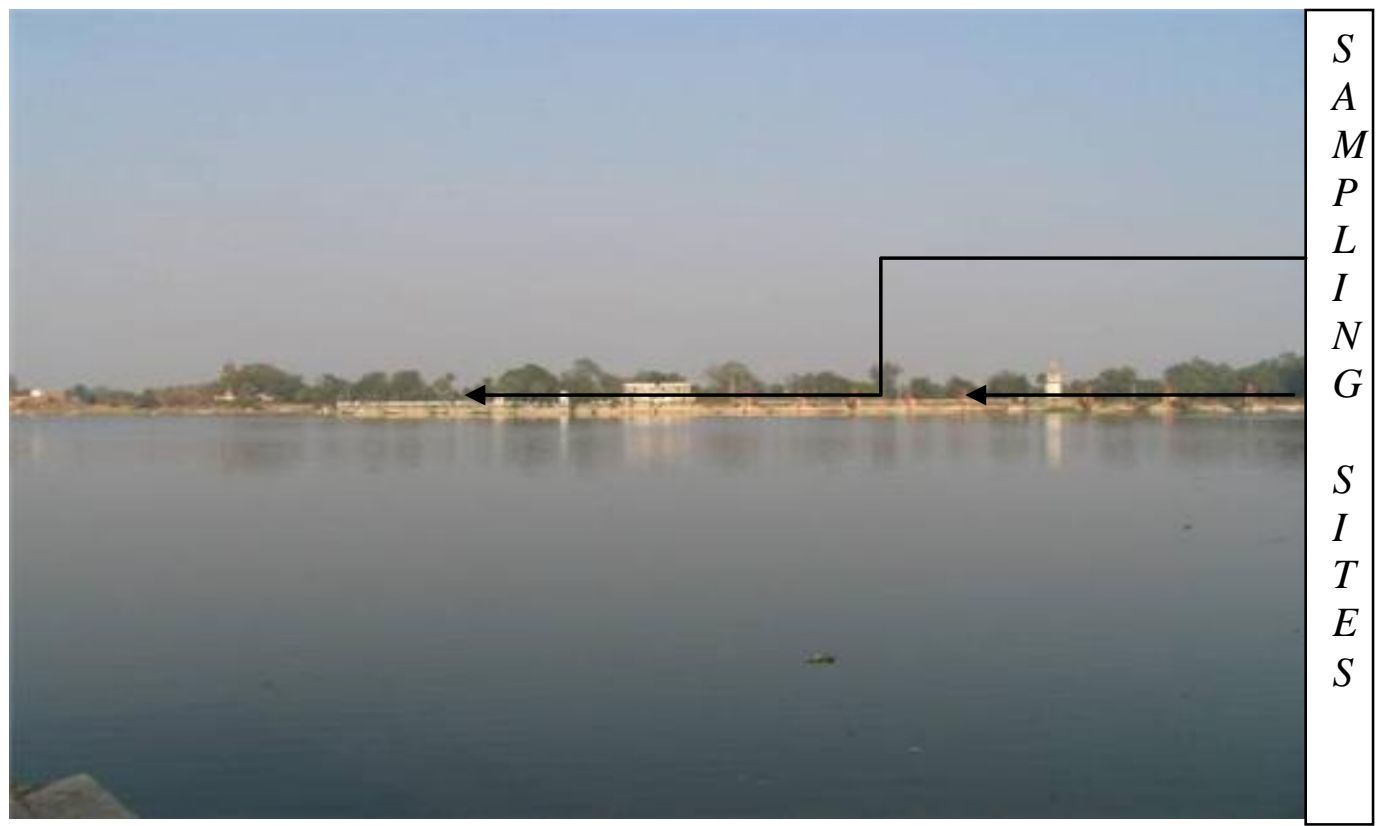

\section{Dissolved oxygen}

The DO values indicate the degree of pollution in the water bodies. Dissolved oxygen is directly related to photosynthesis. During the night, when there is no photosynthesis, the loss of oxygen through respiration is high since there is no counterbalance of oxygen and hence the DO may steadily reduce. Dissolved oxygen varied from 0.90 to $2.40 \mathrm{mg} / \mathrm{l}$ and maximum value recorded in before summer and minimum in after monsoon.

\section{Biological oxygen demand}

BOD is an indication of the organic load and it is a pollution index especially for water bodies receiving organic effluent (Ndimele, 2012). BOD is a chemical procedure for determining the amount of dissolved oxygen needed by aerobic biological organisms in a body of water to break down organic material present in a given water sample at certain temperature over a specific time period. BOD recorded in this experiment maximum in May and Minimum in November which was varied between 8.20 to $4.10 \mathrm{mg} / 1$.

\section{Chemical oxygen demand}

The chemical oxygen demand (COD) test is commonly used to indirectly measure the amount of organic compounds in water. Most applications of COD determine the 
amount of organic pollutants found in surface water making COD a useful measure of water quality. In our study COD was recorded as maximum $215.30 \mathrm{mg} / \mathrm{l}$ and minimum $212.30 \mathrm{mg} / \mathrm{l}$. No significant variation was found in COD analysis during seasonal variation

\section{Total organic carbon}

TOC recorded as range from 88.79 to $90.20 \mathrm{mg} / \mathrm{l}$. It was maximum in summer and minimum in before monsoon

\section{Heavy metal}

In this study some heavy metals were recorded. Zinc was recorded between 1.20 to $1.28 \mathrm{mg} / \mathrm{l}$, Iron was recorded between 2.63 to $2.70 \mathrm{mg} / 1$ and lead was recorded between 0.80 to $0.83 \mathrm{mg} / \mathrm{l}$. In which lead was more concentrated that was harmful for human health and other living beings

\section{Acknowledgements}

The authors are very thankful to the UGC, New Delhi, for financial support and Principal, Bipin Bihari PG degree college, Jhansi for providing necessary research facilities.

\section{References}

Adeniyi, I.F. 2004. The Concept of Water Quality in: Ife Environmentalist, Official Bulletin of Nigerian Society for Environ. Management (NISEM) O.A.U. 1(1).

APHA. 2005. Standard methods for examination of water and wastewater. 21st Edition., Washington D.C.

Choudhury, S.B., \& Panigrahy, R.C. 1991. Seasonal distribution and behaviour o nutrients in the creek and coastal waters of Gopalpur, east coast of
India. Mahasagar-Bull. Nat. Inst. Oceanogr., 24, 81-88.

Devi, M.B., Das T., \& Gupta, S. 2013. Limnological Studies of Temple Ponds in Cachar District, Assam, North East India, I Res. J. Environ. Sci., 2(10), 49-57.

DWAF WRC. 1995. South African Water quality management series. Procedures to assess effluent discharge impacts. WRC Report No TT 64/94. Dept. Water Affairs For. Water Res. Commission, Pretoria.

Fried, J.J., \& Combarnous, M.A. 1971. Dispersion in porous media, $A d v$. Hydrosci., 7, 169-282.

Gopalkrushna, M.H. 2011. Assessment of Physico-Chemical Status of Ground Water Samples in Akot city, Res. J. Chem. Sci., 1(4), 117-124.

Himebaugh, R.R., \& Smith, M.J. 1979. Semi-micro tube method for chemical oxygen demand. Anal. Chem., 51:1085.

Iwuoha, G.N., \& Osuji, L.C. 2012. Changes in Surface Water Physico-Chemical Parameters following the Dredging of Otamiri and Nworie Rivers, Imo State of Nigeria, Res. J. Chem. Sci., 2(3), 711.

Mahananda, M.R., Mohanty, B.P., \& Behera Mahananda, N.R. 2010. PhysicoChemical Analysis of Surface and Ground Water of Bargarh District, Orissa, India, IJRRAS, 2(3).

Matini, L., Tathy, C., \& Moutou, J.M. 2012. Seasonal Groundwater Quality Variation in Brazzaville, Congo, Res. J. Chem. Sci., 2(1), 7-14.

Ndimele, P.E. 2012. The effect of water hyacinth (Eichhornia crassipes [Mart.] Solm.) Infestation on the physicochemistry, nutrient and heavy metal content of Badagry Creek and Ologe Lagoon, Lagos, Nigeria, $J$. Environ. Sci. Tech., 5, 128-136 
Offem, B.O., Ayotunde, E.O., Ikpi, G.U., Ochang, S.N., \& Ada, F.B. 2011. Influence of seasons on water quality, abundance of fish and plankton species of Ikwori lake, South-Eastern Nigeria, Fisheries and Aquaculture, 201, FAJ-13.

Okake, C.O., \& Igboanua, A.H. 2003. Characteristics and quality assessment of surfa ce water and ground water resourcs of Akwa Town, Southeast, Nigeria, J. Niger. Assoc. Hdrol. Geol., 14: 71-77.

Reddi, K.R., Jayaraju, N., Suriya kumar, I., \& Sreenivas, K. 1993. Tidal fluctuation in relation to certain physio-chemical parameters in Swarnamukhi river estuary, East coast of India. Ind. J. Mar. Sci., 22, 232234.

Srivastava, A., \& Srivastava, S. 2011. Assessment of Physico-Chemical properties and sewage pollution indicator bacteria in surface water of River Gomti in Uttar Pradesh, Int. J. Environ. Sci., 2(1), pp 325-336.
Tamrakar, C.S., \& Raj, S.P. 2013. Physicochemical Assessment of Deep Groundwater Quality of Various Sites of Kathmandu Metropolitan City, Nepal, Res. J. Chem. Sci., 3(8), 78-82

Taylor, E.W. 1949. The examination of water and water supplies. J. and A Churchill Ltd, London.

Trivedy, R.K., \& Goel, P.K. 1984. Chemical and Biological Methods for Water Pollution Studies. Environmental Publication, Karad, India.

Vaishnav, M.M., \& Dewangan, S. 2011. Assessment of Water Quality Status in Reference to Statistical Parameters in Different Aquifers of Balco Industrial Area, Korba, C.G. India, Res. J. Chem. Sci., 1(9), 67-72.

Welch, M.N. 1952. Limnol., McGraw Hill Book Co. Inc., New York.

Wetzel, R.G., \& Likens, G.E. 1991. Limnological Analyses, 2nd Edition. Springerverlag, New York.

Williams, P.M. 1969. The determination of dissolved organic carbon in seawater: A comparison of two methods. Limnol. Oceanogr., 14: 297.

\section{How to cite this article:}

Tirthesh Kumar Sharma and Ramendra Singh. 2016. Seasonal Variation in Physico-Chemical Parameters of Water in Laxmi Taal, Jhansi, India. Int.J.Curr.Microbiol.App.Sci. 5(12): 308315. doi: http://dx.doi.org/10.20546/ijcmas.2016.512.033 